\title{
Synthesis
}

\section{The Adaptive Co-Management Process: an Initial Synthesis of Representative Models and Influential Variables}

\author{
$\underline{\text { Ryan Plummer }}^{1,2}$
}

\begin{abstract}
Collaborative and adaptive approaches to environmental management have captured the attention of administrators, resource users, and scholars. Adaptive co-management builds upon these approaches to create a novel governance strategy. This paper investigates the dynamics of the adaptive comanagement process and the variables that influence it. The investigation begins by summarizing analytical and causal models relevant to the adaptive co-management process. Variables that influence this process are then synthesized from diverse literatures, categorized as being exogenous or endogenous, and developed into respective analytical frameworks. In identifying commonalities among models of the adaptive comanagement process and discerning influential variables, this paper provides initial insights into understanding the dynamic social process of adaptive co-management. From these insights conjectures for future inquires are offered in the conclusion.
\end{abstract}

Key Words: adaptive co-management; co-management; environmental governance; resilience; socialecological systems

\section{INTRODUCTION}

In the search for second-generation environmental policy options an overwhelming amount of attention has focused on collaborative management or comanagement. Co-management captures the idea that rights and responsibilities should be shared among those with a claim to the environment or a natural resource. From its early use in the Duero basin in 19th century Spain (see Guillet 2002), comanagement has been applied across a myriad of resource contexts (e.g., fisheries, forestry, wildlife, parks, tourism) throughout the world. Singleton (2002:54) observes that "it would be difficult to find any recent environmental policy initiatives that did not contain prominent references to the need to move away from 'top-down' directives and toward, 'consensus-based' processes and community participation in planning, implementing and monitoring new policies." Related scholarship has flourished in the past 20 years to the point that "... co-management is being heralded as an emergent intellectual tradition that can be used to guide the stewardship of the world's natural resources into the future" (Natcher et al. 2005:40).
The concept of co-management has evolved with both research and experience (see Plummer and Armitage 2007c). Early definitions and representations focused on dualistic power-sharing between the State and local (or indigenous) resource users and the range of possible arrangements (Pinkerton 1989, Berkes et al. 1991, Berkes 1994). Subsequently, the spectrum of individuals potentially involved in comanagement was broadened to include a wider array of actors and co-management was advanced as a continuous problem-solving process (Plummer and FitzGibbon 2004b, Carlsson and Berkes 2005, Plummer 2006). Most recently, the dynamism inherent in the co-management process has been highlighted in relation to knowledge generation, social learning, and adaptation for transformative changes (Berkes 2009).

In merging co-management with adaptive management a distinct approach is engendered that "... represents a potentially important innovation in natural resource governance under conditions of change, uncertainty and complexity" (Armitage et al. 2007:2). Adaptive co-management is depicted as a governance system involving heterogeneous actors and cross-scale interactions (Folke et al. 
2002, Olsson et al. 2004a, Cash et al. 2006, Fabricius et al. 2007). These network connections (horizontal and vertical) facilitate learning through feedback, emphasize social processes that encourage flexibility and build capacity for adaptation (Olsson et al. 2004a, Berkes 2004, Folke et al. 2005, Plummer and Armitage 2007b, Armitage et al. 2009). Olsson et al. (2004a:87) argue that adaptive co-management “... creates an 'adaptive dance' between resilience and change with the potential to sustain complex social-ecological systems." Although it is important to recognize that adaptive co-management is not a governance panacea, conditions that contribute toward successful outcomes are starting to emerge from practice. These include: well-defined resource systems and small-scale contexts; shared interests by an identifiable set of social entities; clear property rights; access to adaptable management measures; commitment to a long-term process of institution building; availability of training and resources; presence of key leaders or champions; openness of participants to embrace plurality of knowledge; and a supportive policy environment (Armitage et al. 2009).

Missing from the above conceptual investitures are knowledge and representation of how the process of adaptive co-management occurs. This is partially due to the relatively small number of case studies documenting and describing experiences with adaptive co-management. However, this lacuna extends beyond adaptive co-management to the more general area of collaborative natural resource management. Nkhata et al. (2008) observe that "notwithstanding a growing appreciation of the importance of collaboration, little attention has been explicitly given to the dynamic long-term social relationships that underlie collaborative schemes in the management of SESs." This void raises several important questions. Is there a general process of adaptive co-management? Can a representation of the phenomena be derived? What variables influence the process of adaptive co-management? How do these influential variables relate to the adaptive co-management process?

This paper is an initial effort to gain insight into these questions by integrating recent work from different literatures. It specifically aims to: (1) summarize existing models with pertinence to understanding the process of adaptive comanagement; (2) identify variables that influence the process of adaptive co-management through a synthesis of antecedent literature (i.e., develop an analytical framework); and (3) suggest avenues for pursuing future research. The nature and structure of the paper reflects these objectives. It begins by presenting models that advance understanding of the adaptive co-management process. Consistent with the nature of this paper and the theoretical formats or schemes outlined by Turner (1994), the focus on models involves inherent abstraction from empirical evidence, representation of the phenomena, and analytical or causal characteristics. Co-management and adaptive management representations provide a point of departure, from which attention is specifically directed to the recent emergence of models allied with the resilience approach that stress adaptation and transformation. A synthesis of the literature related to adaptive comanagement follows to glean variables that influence the adaptive co-management process. Conjectures about the process of adaptive comanagement and avenues for future research to advance its understanding are raised in the concluding comments.

\section{INSIGHTS INTO ADAPTIVE CO- MANAGEMENT FROM ANALYTICAL AND CAUSAL MODELS}

The introductory remarks of this paper assert that adaptive co-management is the outcome of merging co-management and adaptive management. Although adaptive co-management is distinct from either approach, the presence of existing models in this lineage provides a logical starting point to begin gathering insights.

Conceptualizations of co-management have changed as understanding of the phenomenon has evolved and develop through experience and research. Plummer and Fennell (2007) document and describe these changes in their exploration of co-management theory according to modeling, propositional, analytical and met-theoretical schemes or formats. They specifically categorized representations (models) of co-management according to intent. Analytical models aim to abstractly embody the phenomena without being connected to a particular case. Examples of models in this category include: Pomeroy and Berkes' (1997) hierarchy of co-management arrangements; Plummer and FitzGibbon's (2004b) proposed conceptual framework of co-management; and Carlsson and Berkes' (2005) five images of co- 
management. Although Plummer and FitzGibbon (2004b) synthesize the inputs (antecedents or preconditions) and the outcomes associated with comanagement, the "interactive process of collaboration" remains abstract in their model and it offers relatively little guidance as to what actually occurs in the process. Causal models aim to represent relationships and explain how processes work in light of a particular case. Although causal models depicting collaboration exist in communicative planning (Booher and Innes 2002) and environmental management (Selin and Chavez 1995, Allen et al. 2001), few depictions of the specific process by which co-management develops exist. Plummer's (2006) modeling of the comanagement process along a river corridor offers unique insights in this regard. The phenomenon of co-management in this case is represented by three stages. The first stage is characterized as independence, and interactions among the actors involved (government resource agency representatives, landowners, and stakeholders) did not occur. In the second stage, association, the actors began to interact. In this particular case of co-management, a distinction is evident between the resource agencies (who focused on technical aspects, were concerned about resources, and cognizant of issues in engaging the community) and the other actors, who concomitantly engaged in communicative processes articulating resource values that led to a shared vision. A distributor switch is used in the model to indicate that multiple pathways are evident in this second stage. Feedback occurs by learning about different perspectives. In third stage of integration, a different pathway is taken in which the group collectively undertakes a task and shares the consequences of their action. Although his original aim was to model the co-management process, Plummer (2006) explicitly recognizes in his closing comments the adaptive character of the process (flexibility, multiple feedback loops, learning) represented.

Adaptive management was developed by Holling (1978) and Walters (1986) as a response to the complexity and uncertainty. It stresses "learning by doing" and undertaking actions and policies as experiments (Walters and Holling 1990, Jiggins and Rölling 2000, Lee 1993, Gunderson et al. 2008). Although a single model or framework of adaptive management does not exist, agreement is coalescing around common components (Noble 2004). Analytical models visually portray adaptive management as a circle to represent an ongoing or iterative process. The process of adaptive management generally involves monitoring and assessing conditions interspersed with components of: scoping or assessing opportunities, designing policy options or experiments, implementing or taking action, and evaluating and adjusting (Walters and Holling 1990, McLain and Lee 1996, Noble 2004, Gunderson et al. 2008). An abundance of case studies detail the application of adaptive management from individual species to large ecosystems as well as critique the approach. McLain and Lee (1996) observe that, although adaptive management emphasizes social interaction, relatively little attention has been directed to aspects such as institutions. Johnson (1999) comes to a similar conclusion and asserts that adaptive management faces social challenges as opposed to scientific ones. Walters (2007), reflecting upon the more than 100 case studies of adaptive management in fisheries alone, observes that most of the cases resulting in "failures" were due to institutional problems of: lacking resources to conduct largescale experiments; unwillingness by decision makers to acknowledge uncertainty in policy choices; and absence of leadership and other actors to carry out the required hard work. Given the above "social challenges," recent emphasis has shifted to: exploring how adaptive management connects with collaboration or co-management; probing the ways in which social learning may occur; and investigating how flexible governance structures and institutions may be fostered (e.g., Keen and Mahanty 2005, Hughes et al. 2007, Gunderson et al. 2008, Huitema et al. 2009). As Berkes (2009) and Huitema et al. (2009) have recently identified, both scholars and practitioners of adaptive management have and are now practicing adaptive co-management without using that particular name. An example of explicitly bringing together the collaborative and adaptive management approaches is the model of co-learning offered by Keen and Mahanty (2005). In applying it to consider two cases of the Biodiversity Conservation Network, they underscore the importance of power relations and communication and knowledge.

The "resilience approach" (sensu Anderies et al. 2006) provides a useful lens to consider the adaptive nature of collaboration in social-ecological systems and social systems (see Holling and Gunderson 2002, Westley 2002). The adaptive cycle is the centerpiece of the resilience approach as it enhances understanding of system dynamics and transformations. Although initially described by Holling (1986) with 
reference to ecological systems, the adaptive cycle is now recognized as an applicable metaphor for social systems and social-ecological systems (Walker et al. 2006, Folke 2006). In an effort to move away from the rigid connotations associated with employment of the term hierarchy, the concept of panarchy is used to refer to a nested set of connected adaptive cycles that differ in speed and scale (Holling et al. 2002, Folke 2006). Fast variables function at a small scale, provide opportunities for novelty and experimentation, and precipitate cascading changes (in structure and function) of the system by overwhelming slower variables (Holling et al. 2002). Slow variables function at larger temporal and spatial scales and foster stability and legacy to systems (Holling et al. 2002). Although several connections may exist among levels, attention is focused on the "revolt" connections in which small and fast variables destabilize larger ones and potentially have cascading influences on the entire system as well as the "remember" connections that provide stability and a repository of resources from large slowmoving variables (Holling et al. 2002, Armitage and Johnson 2006, Folke 2006). Resilience comes from the nested cycles and interactions among the fast and slow variables that influence the adaptive cycle (Holling 2001).

Scheffer et al. (2002) have taken an interdisciplinary approach (ecology, economics, and sociology) to examine interactions of society and ecosystems. They observe that the concepts of turbulent fields (Emery and Trist 1965) and interorganizational problem domains (Trist 1983, Gray 1989) established in organizational theory frame contemporary ideas associated with complex systems in sociological terms. Their discussion of factors that govern domain structure and the dynamic nature of problem domains leads to the conclusion that "...these domains often move through more or less predictable patterns of transformation" (Scheffer et al. 2002:233). Applying the adaptive-cycle metaphor to domain transformations after a problem emerges becomes a function of connectedness and social capital. Scheffer et al. (2002) assert this process is continuous and resembles "something like" the four-box adaptive cycle. In the scattered phase, a few stakeholders in the domain recognize a problem and relatively few social links exist. As awareness of the problem increases so do the capital and connections of the group (mobilize phase). The group continues to secure resources and attempts to change norms (polarized phase). Changes in collective values may become codified in the final institutionalized phase. The cycle may be reinitialized as the environment changes. Dyball et al. (2005) use the adaptive cycle as a "mental model" to analyze the case of social learning associated with the lower Macleay River catchment in Australia. Their findings challenge the pattern presented in the adaptive cycle as the reorganization phases expanded to include multiple practices that, if successful, led directly to the conservation phase. More recently, Nkhata et al. (2008) pose a framework for analyzing changes in long-term social relationships by drawing upon relationship theory (see Cousins 2002) and resilience "theory." The adaptive-cycle heuristic is modified in their model by replacing stored capital with relational capital (e.g., trust, commitment) and changing connectedness to relational connectedness (i.e., degree and strength of links between actors in social relationships). These variables act as the basis for change in long-term relationships as they move through a cycle of being opportunistic (growth and exploitation), collaborative (conservation), adversarial (release), and tactical (reorganization).

As many of the individuals advancing the resilience approach share an interest in adaptive comanagement, it is unsurprising that the metaphor of the adaptive cycle and panarchy have been used to model the process of adaptive co-management. Colfer (2005) provides a rich analysis of undertaking adaptive collaborative management at 30 sites world wide through participatory action research by the Center for International Forestry Research (CIFOR). She makes specific connections between their approach (i.e., the worm or process of participatory action research) and the adaptive renewal cycle, asserts that several of the cases (social and ecological) move through the four phases, and emphasizes that the idea of panarchy (especially the revolt and remember connections) fit nicely with the observations from those 30 sites. Seixas and Berkes (2003) have analyzed the Ibiraquera Lagoon fishery in Brazil by combining the common-property and resilience approaches. Their analysis of this social-ecological system includes: modeling the ecosystem according to Holling's (1986) adaptive renewal cycle and the nested relationship in the larger ecosystem; depicting the history of the lagoon and fisheries management as successive iterations of the adaptive 
renewal cycle; and describing how "traditional" management practices conferred resilience by locating them each of the four phases of the adaptive renewal cycle. Doubleday (2005) has also modeled the adaptive co-management process using the adaptive renewal cycle. Focusing on experiences of Aboriginal peoples in Canada's north, she stresses the need to go beyond the "formal" socialecological systems perspective and to recognize the importance of culture. In taking a longitudinal view, she depicts the system (cultural, ecological, and social) changing through land-claims policy (precontact, colonization, recognition of rights, and post-settlement) and adaptive co-management to take on a development role to nurture change.

One of the most studied examples of adaptive comanagement and one of the first causal models depicting this process is of the Kristianstads Vattenrike area of Sweden (Olsson et al. 2004a, 2004b, 2006, 2007, Olsson 2007, Schultz 2009). Located in the Municipality of Kristianstad, these vast wetlands cover an area of 110000 ha and include the Helgeå River, which drains a catchment area of $4775 \mathrm{~km}^{2}$. In the early $1970 \mathrm{~s}$, an individual working for the Kristianstads County Museum envisioned an opportunity to draw attention to the wetlands by incorporating information into a natural history exhibit, which specifically focused on the shrinkage of wetlands and the associated causes. Through an extensive series of investigations, the events and processes that have occurred over the past 35 years have been documented. Olsson et al. (2004b) have specifically identified three phases in the Swedish case. Phase one (preparation) involved a key individual (SEM) developing knowledge about the area, building social relationships and networks, and proving a future vision of the area. Phase two (window of opportunity) involved forming the EKV by taking advantage of a "policy window." Phase three (building resilience) encompassed the informal and learning functioning of the EKV, in which networks and links continued to develop. Transformability and adaptability in the Kristianstads Vattenrike case have received extensive attention and are well documented (Olsson et al 2004a, 2004b, 2007, Olsson 2007). The ability to access social memory of local steward groups through networks, activate links or bridge organizations across levels (modeled as linking clusters of networks), and address problems at multiple scales has been documented as a source of resilience in the Kristianstads Vattenrike (see Olsson et al. 2007, Olsson 2007, Schultz 2009).
Models are a specific theoretical format or scheme (sensu Turner 1994) that represents a phenomenon in an analytical or causal manner. In summarizing the above models with pertinence to adaptive comanagement, several insights are gleaned. Analytical models that represent the component parts of the phenomena have emerged after a critical mass of applied experience and empirical evidence has been gathered. Analytical models of comanagement (Plummer and FitzGibbon 2004a, Carlsson and Berkes 2005) are a good example of where researchers have drawn upon more than 15 years of evidence to abstractly capture the phenomenon. Attempts to develop causal models that explain how processes work in light of a particular case by identifying components and describing relationships are relatively scarce in comanagement and adaptive management. In synthesizing models with pertinence to understanding the process of adaptive co-management, several specific efforts were identified above. These consider the social process of collaboration from the resilience approach and/or, more specifically, the process of adaptive co-management. Although a single definitive model does not emerge from the synthesis, the following important commonalities are noted. First, models pertaining to adaptive comanagement suggest the process consists of a relatively small number of distinct phases. Second, all of the models signal that adaptive comanagement is a dynamic process with continuous change occurring between the different phases. Third, several of the models represent adaptive comanagement as a process occurring across levels and at multiple scales. In this regard, the models draw extensively upon the resilience approach, the metaphor of the adaptive cycle as a stylized representation of change, and panarchy as a representation of multi-scale interactions.

\section{WHAT VARIABLES INFLUENCE THE PROCESS OF ADAPTIVE CO- MANAGEMENT?}

Synthesis of the aforementioned models suggests that adaptive co-management encompasses multiple phases, is dynamic, and involves multi-scale interactions. Discerning these observations raises the prospect of understanding what variables influence the dynamic process of adaptive comanagement. This section brings together and organizes research to offer preliminary insights into this conjecture. It specifically aims to identify 
critical variables from the literature that influence the dynamic process of adaptive co-management and to arrange these variables into analytical frameworks that may be useful for future research.

The resilience approach described above provides a useful starting point to identify these variables because it focuses on the dynamism of socialecological systems. The concept of change is inherent in the adaptive cycle and panarchical connections. Transformability and adaptability are important accompanying properties of socialecological systems related to resilience. The former refers to the potential for fundamental change in light of untenable existing circumstances, and the latter concerns the capacity of actors to influence resilience (Westley et al. 2002, Walker et al. 2006). In seeking to understand the dynamism of ecological and social systems, a small number of critical variables that operate at different speeds have been identified (see Holling et al. 2002). An important issue to note when considering socialecological systems is the inherent connectivity that makes them a system, the expression of those connections over a range of scales, and the reflection of those connections in the system states and determinant variables (see Scheffer et al. 2002, Cash et al. 2006). Organizational devices are conceptually useful to assist in making sense of complex systems and complicated multifaceted relationships. Ostrom (2007:15181) cautions against becoming fixated on "...a low conceptual hill related to specific variable..." and encourages the "...need to recognize and understand complexity in order to develop diagnostic methods to identify combinations of variables that affect the incentives and actions of actors under diverse governance systems." In this regard, she advances a multi-tier framework for analyzing a social-ecological system. Armitage (2005) provides a more narrowly focused example by constructing a framework to better understand the influences on communitybased natural resource management processes in relationship to the construct of adaptive capacity. In this framework, variables and their relationship to adaptive capacity are considered as being endogenous or exogenous. More recently, Alessa et al. (2009) have offered an initial framework for messy social-ecological systems according to continuums of community size and resilience. Within their framework, exogenous events “... represent outside social-ecological occurrences over which a community has little or no direct control, but to which it can respond and mitigate undesirable outcomes" (Alessa et al. 2009:32-33). In following the aforementioned frameworks, the variables synthesized from the literature that influence the process of adaptive co-management are categorized as being exogenous or endogenous.

Exogenous variables largely originate outside the network of actors that constitute adaptive-comanagement and contribute to transformability. Consistent with the work of Alessa et al. (2009), these variables are outside the direct control of the network of actors who constitute adaptive comanagement. However, these variables have a bearing on adaptive co-management by influencing the real or perceived circumstances of the actors involved. Exogenous variables are summarized in Table 1 . The scale of these variables is diverse and ranges from local to global. Ecosystem changes or resource alterations that are a real or imagined crisis are a well-established precondition to comanagement (Pinkerton 1989, Selin and Chavez 1995) and adaptive co-management (e.g., Olsson et al. 2004b, Kearney and Berkes 2007, McConney et al. 2007, Armitage et al. 2009). Legal mandates, policies prescriptions, and availability of resources by local governments often also induce action (Selin and Chavez 1995, Pomeroy and Berkes 1997, Fresque 2008). These variables appear to be especially powerful in catalyzing the process early on and have been labeled preconditions or antecedents to co-management (Pinkerton 1989, Plummer and FitzGibbon 2004b) and also discussed in relation to the early phase of the adaptive comanagement process (e.g., Olsson et al. 2004b, Berkes 2007, Armitage et al. 2009).

Other exogenous variables that influence the process of adaptive co-management are less obvious. Kearney and Berkes (2007) point out that communities or the local scale at which adaptive comanagement processes typically unfold should more accurately be thought of as complex systems; these systems are further embedded in larger systems, and the impacts of multiple external drivers often have a confounding impact. Recent adaptive co-management literature is shedding light on some of these variables, which are part of larger social systems. Culture is one such variable that is starting to receive attention for its influence on adaptive comanagement (Berkes and Folke 1998, Folke et al. 2003, Kristofferson and Berkes 2005, Doubleday 2007). Kristofferson and Berkes (2005), for example, have documented how traditional knowledge and scientific information can be 
Table 1. Analytical framework of exogenous variables influencing the process of adaptive co-management.

Exogenous Variables

Ecosystem changes or resource alterations that precipitate crisis. The crisis may be real or of perceived importance to the actors involved.

Legal mandates, policy prescriptions, and/or resources support (or reductions) by government.

Social and political context in which adaptive comanagement is embedded. Variables emerging with specific influence include:

Culture

Knowledge systems

Power

"Meso-scale" social and economic drivers that propel other exogenous variables as well as endogenous variables. Examples include population, international trade, and globalization.
Key References

Pinkerton 1989, Selin and Chavez 1995, Olsson et al. 2004b, McConney et al. 2007, Armitage et al. 2009

Pinkerton 1989, Plummer and FitzGibbon 2004a, Olsson et al. 2004b, Berkes 2007, Fresque 2008, Armitage et al. 2009

Berkes and Folke 1998, Folke et al. 2003, Kristofferson and Berkes 2005, Natcher et al. 2005, Doubleday 2007

Olsson et al. 2004b, Kristofferson and Berkes 2005, Armitage 2007, Berkes 2009

Armitage 2007, Doubleday 2007, Nadasdy 2003, 2007, Fennell et al. 2008, Armitage et al. 2009

Folke et al. 2003, Armitage and Johnson 2006, Armitage 2008 positively incorporated into an adaptive comanagement approach for Arctic char in Cambridge Bay, Nunavut, Canada. Doubleday (2007) presents the case of Cape Dorset, Nunavut, Canada, and the issue of community justice to illustrate the role of the cultural context in which adaptive comanagement operates or is embedded. Another variable garnering attention is power or manifestations of control (Doubleday 2007, Nadasdy 2003, 2007, Fennell et al. 2008, Armitage et al. 2009). Nadasdy (2007), for example, takes an anthropological approach to explore the case of the Ruby Range Sheep Steering Committee in the Yukon. He identifies that political and economic inequities experienced by the Kluane people are central to their concerns regarding the sheep and that, if they had agreed to participate in the adaptive co-management process, it would have made them complicit in their own marginalization, noting explicitly that all management processes are embedded in political and economic contexts. Fennell et al. (2008) use good governance as an entry point to query if adaptive co-management is ethical. They explore the case of Cambodia and, among other findings, recognize that such strategies may be influenced by international donors and enacted in the absence of understanding specific social-ecological characteristics. Propelling the above variables, as well as others such as resource intensification and commodification, are broader economic forces such as globalization, international trade, technology, and so on (Folke et al. 2003, Armitage and Johnson 2006, Armitage 2008). Folke et al. (2003) refer to these external social and economic drivers as meso-scale drivers and observe that as globalization tightens the connection 
between resource users and society the risk for weakening feedback loops with ecosystem dynamics increases, leading to the need for new levels of governance.

Endogenous variables are those that largely originate from within the adaptive co-management network. As these influential variables concern the network of actors who constitute adaptive comanagement, adaptability is the main focus. As presented in Table 2, the main variables emerging from the literature relate to social networks, individuals, and organizations.

Descriptions of adaptive co-management routinely emphasize the presence of a network and/or network connections that facilitate or make possible the flexible and adaptable (learning) process (Olsson et al. 2004a, Berkes 2004, Folke et al. 2005, Plummer and Armitage 2007b, Armitage et al. 2009). In reviewing the evolution of co-management, Berkes (2009) emphasizes the importance of networks in relation to generating knowledge, bridging organizations, and social learning. The contributions of networks to building resilience and increasing adaptive capacity have also been identified (see Tompkins and Adger 2004). However, not all social networks are equal (Newman and Dale 2005, Bodin et al. 2006, Bodin and Crona 2009). Social networks are not simple pathways, but rather multidimensional constructs (see Newman and Dale 2005, Bodin et al. 2006). They both give structure to adaptive comanagement and influence how it functions through their properties. Three properties of networks are emerging from recent research on the relationships between network structures and functions that have salience for adaptive co-management. The first property concerns the nature of the structure and the types of links it emphasizes: these connections can be strong and between individuals in a group or community (bonding) or vertical and extend to heterogeneous individuals and organizations (bridging). Newman and Dale (2005) contend that a dynamic balance is required between bonding and bridging links. The second property concerns the centrality and the manner in which links and nodes are distributed. High centrality may facilitate some tasks (e.g., the speed of information sharing, decision making, and coordination) and inhibit others (e.g., decreasing sharing of risk) (Bodin et al. 2006). A third influential property of networks is connectivity, which is concerned with the density of the links; connectivity can be a positive influence to enhance trust and decrease costs (high density), access information from actors (high reachability) and increase feedback possibilities (high modularity) (see Bodin et al. 2006, Janssen et al. 2006). Caution should also be exercised as high connectivity can also influence homogenization and isolation of group positions (Bodin et al. 2006). Bodin and Crona (2009) provide a comprehensive review and synthesis of empirical literature on social networks in relation to natural resource governance and adaptive co-management. In looking forward from their summary, Bodin and Crona (2009) argue that governance processes can benefit from: balancing structural characteristics and synchronizing them with governance phases; facilitating network creation and incorporating social network analysis as part of facilitating stakeholder participation; and understanding the dynamism and cross-scale interactions of social networks.

Social networks connect the actors (individuals, organizations, agencies) who are involved in adaptive co-management. Each individual, organization, or agency has specific assets and attributes that influence adaptability. Plummer and Armitage (2007c), for example, draw upon a sustainable livelihoods framework (Chambers and Conway 1991, Scoones 1998, Farrington et al. 1999) to recognize the interconnections between the complicated suite of social-economic realities and governance strategies, such as adaptive comanagement. Endowments and/or entitlements that enable access to livelihood assets are significant, as summarized in Table 2. The attributes held by individuals, organizations, and agencies are also powerful. Attributes identified to influence adaptive co-management include: leadership, emotions, capacity, experience, and interpersonal skills (see Table 2). Among these attributes, qualities of leadership have received particular recognition and their influence on adaptive co-management is extensively documented (Pinkerton 1989, Olsson et al. 2004b, 2006, 2007, Fresque 2008).

Although exogenous and endogenous variables have been synthesized from the literature, it is imperative to recognize that their influences are not mutually exclusive; it is often some combination of variables that impact the dynamics of adaptive comanagement. Klijn and Edelenbos (2007:213), for example, observe that "the structural position of the network actors is an important source of influence of formal authority, knowledge, money, organizational capacities, etc.," an observation confirmed in the comprehensive summary by Bodin and Crona 
Table 2. Analytical framework of endogenous variables influencing the process of adaptive comanagement.

\section{Properties of Networks}

(Newman and Dale 2005, Bodin et al. 2006, Janssen et al. 2006, Sørensen and Torfing 2007, Bodin and Crona 2009)

Connectivity

- density

- reachability

- betweeness
Centrality

- distribution of links and nodes
Structural importance

- bridging

- bonding

Assets Employed by Agencies, Organizations and Individuals

(Plummer and Armitage 2007a)

\begin{tabular}{|c|c|c|c|c|}
\hline $\begin{array}{l}\text { Human capital } \\
\text { - skills } \\
\text { - knowledge } \\
\text { - health }\end{array}$ & $\begin{array}{l}\text { Social capital } \\
\text { - networks } \\
\text { - relationships of trust and } \\
\text { reciprocity }\end{array}$ & $\begin{array}{l}\text { Natural capital } \\
\text { - stocks } \\
\text { - ecological services }\end{array}$ & $\begin{array}{l}\text { Physical capital } \\
\text { - infrastructure } \\
\text { - goods }\end{array}$ & $\begin{array}{l}\text { Financial capital } \\
\text { - cash } \\
\text { - livestock } \\
\text { - inflows of money }\end{array}$ \\
\hline
\end{tabular}

Attributes of Organizations and Individuals

(Westley 2002, Folke et al. 2005, Crona and Bodin 2006, Fabricius et al. 2007, Olsson et al. 2007, Armitage et al. 2009, Berkes 2009)

\begin{tabular}{|c|c|c|c|c|}
\hline $\begin{array}{l}\text { Leadership } \\
\text { - vision } \\
\text { - ability to exert influence } \\
\text { - authority }\end{array}$ & $\begin{array}{l}\text { Emotions } \\
\text { - perceptions } \\
\text { - values } \\
\text { - attitudes }\end{array}$ & $\begin{array}{l}\text { Capacity } \\
\text { - aptitude for learning } \\
\text { - aptitude to change } \\
\text { - willingness to experiment }\end{array}$ & $\begin{array}{l}\text { Experience } \\
\text { - history }\end{array}$ & $\begin{array}{l}\text { Interpersonal skills } \\
\text { - communication } \\
\text { - openness } \\
\text { - social skills } \\
\text { - conflict resolution }\end{array}$ \\
\hline
\end{tabular}

Key Functions of Individuals

(Folke et al. 2003, Folke et al. 2005, Berkes 2009)

\begin{tabular}{|c|c|c|c|c|c|c|}
\hline Knowledge & Interpreters & Networkers & Stewards and & Visionaries and & Entrepreneurs & Followers \\
\hline - retain memories & $\begin{array}{l}\text { - make information } \\
\text { and knowledge } \\
\text { accessible }\end{array}$ & $\begin{array}{l}\text { - connects actors } \\
\text { - facilitates } \\
\text { interactions }\end{array}$ & $\begin{array}{l}\text { - } \text { often embodies } \\
\text { other functions as } \\
\text { well }\end{array}$ & $\begin{array}{l}\text { - initiate and } \\
\text { inspire change } \\
\text { - willing to } \\
\text { experiment }\end{array}$ & $\begin{array}{l}\text { - implementers of } \\
\text { innovation }\end{array}$ & $\begin{array}{l}\text { - willing } \\
\text { and } \\
\text { working } \\
\text { participants } \\
\text { - reinforce } \\
\text { values }\end{array}$ \\
\hline
\end{tabular}

(2009). Folke et al. (2005:454) contend that "many patterns of adaptive co-management can be understood by personal traits, and these traits combined with the roles of teams or actor groups are important factors for building adaptive capacity and provide a source of social resilience in socialecological systems." In combining assets and attributes, individuals and organizations play several key functions within the process of adaptive co-management (Folke et al. 2003, 2005), as summarized in Table 2. Interest is intensifying recently in particular about the functions of organizations to link or bridge other networks as well as to provide leadership (Olsson et al. 2007, Berkes 2009, Schultz 2009).
Although inquiries into understanding interactions among the above variables and their collective influence(s) on the pattern of adaptive comanagement are nascent, there are emerging examples of research starting to move in this direction. Armitage (2007), for example, uses the case of Narwhal management in Nunavut, Canada, to probe the connection among livlihoods, adaptive capacity, and adaptive co-management. In so doing, he focuses on socio-institutional relationships to illustrate nuanced subtext among variables of power, knowledge, and worldviews. Plummer and FitzGibbon's (2007) investigation of river corridors in Ontario, Canada offers initial insights about how deliberative processes enable social learning and 
build social capital, which influences adaptive comanagement. Olsson et al. (2007) build upon previous work in the Kristianstads Vattenrike Biosphere Reserve to emphasize the issue of fit between institutions and ecosystems. This involves multiple levels while concomitantly being aware of the interplay between system dynamics, adaptive structures, bridging organizations, and leadership support. Tables 1 and 2 are offered as analytical frameworks to assist with identifying variables that influence the adaptive co-management process and to consider the interactions among the variables.

\section{CONCLUDING REMARKS}

Adaptive co-management is receiving considerable attention as an innovative governance strategy to sustain social-ecological systems. Although a single model of adaptive co-management did not emerge from the synthesis, the insights offered from summarizing pertinent analytical and causal models enhance understanding of the adaptive comanagement process by recognizing that it involves a relatively small number of distinct phases, is dynamic with discernable shifts between the phases, and occurs across multiple scales. These insights prompted further inquiry about the variables that influence or shape the process of adaptive comanagement. A review of the literature relevant to adaptive co-management revealed that several influential variables exist. These variables were categorized as being exogenous or endogenous and arranged into analytical frameworks (Tables 1 and 2). This paper thereby contributes to the quickly expanding conceptual foundations of adaptive comanagement by integrating recent work from different literatures. More specifically, it addresses the need for attention to the dynamic long-term social relationships associated with management of social-ecological systems as called for by Nkhata et al. (2008). It also offers a starting point to several aspects of the common research agenda between adaptive co-management and governance scholars as called for by Huitema et al. (2009). In building upon the insights gained from the above sections, some of the most promising avenues for pursuing future research about the process of adaptive comanagement are offered in this section.

Although this paper identifies some initial commonalities among models pertinent to adaptive co-management, concerted effort is required to undertake systematic and comparative analysis of the process across various contexts. The commonalities synthesized from the literature reviewed in this paper provide a starting point for researchers interested in undertaking this challenge. It will be necessary to continue to look beyond semantic differences or labels affixed to particular phases and come to a shared understanding of what constitutes phases of the adaptive co-management process. The discussion of analytical and causal models in this paper underscores the need for consistent terminology and commonly agreed upon measures. Only by systematically examining the essence of what is being observed in the adaptive co-management process will a pattern or model be arrived at with cross-case consistency.

The analytical frameworks developed in this paper are the outcome of integrating different literatures and identify exogenous (Table 1) and endogenous (Table 2) variables that influence adaptive comanagement. As experiences with adaptive comanagement are relatively recent, further consideration and refinement of these frameworks and the variables therein are required in light of grounded case studies. Enhancing knowledge of the role(s) of any one variable in the adaptive comanagement process is an important task. In this regard, understanding how adaptive co-management becomes possible (i.e., Fabricius 2007, Armitage et al. 2007) is enhanced by continuing to research the endogenous variables that underlie or make possible the social processes associated with it. Literature brought together in this paper demonstrates that endogenous variables (network properties, assets, attributes, and functions) relate to and can induce phases of the adaptive co-management process. Continued and further attention to these "fast variables" at small scales will yield important insights into the nuances of this process and will complement recent insights about conditions that contribute toward successful outcomes in adaptive co-management (Armitage et al. 2007, 2009).

Although enhancing knowledge about the role(s) of any one variable in the adaptive co-management process is challenging, understanding how multiple variables (exogenous and endogenous) combine to precipitate shifts between phases is a formidable task. Deciphering the relationship(s) between "fast variables" and those functioning at larger and slower scales may provide valuable insights into what precipitates shifts between phases in the adaptive co-management process. What are the tipping points (Gladwell 2000) in the adaptive co- 
management process? Reviewer B asked the following critical questions: (1) to what extent can the variable can be traded off? (2) which variables always need to be present? and (3) which variables are not required for the emergence of adaptive comanagement, but whose presence can improve its quality? These are important questions to pursue in future research.

Ruitenbeek and Cartier (2001) identify the issue of emergence as a critical question and strongly challenge the appropriateness of policies that introduce or impose adaptive co-management as a packaged strategy. They contend that the aims of policy ought to protect and contribute to the conditions for emergence of adaptive comanagement as well as enhance the consciousness of agents in the system. More recently, attention has been focused on the appropriateness and productiveness of interventions in terms of navigating and nurturing resilience in socialecological systems (Berkes et al. 2003, Schultz 2009). As Reviewer B very astutely pointed out, once the variables and their relationship to the phases of the process are better understood the bigger challenge remains of connecting these to facilitate more effective adaptive co-management and ultimately help sustain complex socialecological systems.

Responses to this article can be read online at: http://www.ecologyandsociety.org/voll4/iss2/art24/ responses/

\section{Acknowledgments:}

Ideas for this paper have been shaped by ongoing dialog and collaborative work with DerekArmitage, as well as recent discussions with colleagues at the Stockholm Resilience Centre. I would like to thank Derek Armitage and Bryan Poirier for providing feedback on earlier versions of this paper, as well as Lance Gunderson, the subject editor, and two anonymous reviewers for their valuable insights and feedback. Support for my research in the area of adaptive co-management is provided by the Social Sciences and Humanities Research Council of Canada and the Chancellor's Chair for Research Excellence at Brock University.

\section{LITERATURE CITED}

Alessa, L., A. Kliskey, and M. Altaweel. 2009. Toward a typology for social-ecological systems. Sustainability: Science, Practice, and Policy 5 (1):31-41.

Allen, W. J., O. J. H. Bosch, M. J. Kilvington, D. Harley, and I. Brown. 2001. Monitoring and adaptive management: addressing social and organizational issues to improve information sharing. Natural Resources Forum 25(3):225-233.

Anderies, J. M., B. H. Walker, and A. P. Kinzig. 2006. Fifteen weddings and a funeral: case studies and resilience-based management. Ecology and Society 11(1): 21. [online] URL: http://www.ecolog yandsociety.org/vol11/iss1/art21/.

Armitage, D. 2005. Adaptive capacity and community-based natural resource management. Environmental Management 35(6):703-715.

Armitage, D. 2007. Building resilient livelihoods through adaptive co-management: the role of adaptive capacity. Pages 62-82 in D. Armitage, F. Berkes and N. Doubleday, editors. Adaptive comanagement: collaboration, learning and multilevel governance. University of British Columbia Press, Vancouver, British Columbia, Canada.

Armitage, D. 2008. Governance and the commons in a multi-level world. International Journal of the Commons 2(1):7-32.

Armitage, D., F. Berkes, and N. Doubleday. 2007. Introduction: moving beyond co-management. Pages 1-18 in D. Armitage, F. Berkes, and N. Doubleday, editors. Adaptive co-management: collaboration, learning and multi-level governance. University of British Columbia Press, Vancouver, British Columbia, Canada.

Armitage, D. R., and D. Johnson. 2006. Can resilience be reconciled with globalization and the increasingly complex conditions of resource degradation in Asian coastal regions? Ecology and Society 11(1): 2. [online] URL: http://www.ecology andsociety.org/vol11/iss1/art2/.

Armitage D. R., R. Plummer, F. Berkes, R. I. Arthur, A. T. Charles, I. J. Davidson-Hunt, A. P. Diduck, N. Doubleday, D. S. Johnson, M. 
Marschke, P. McConney, E. Pinkerton, and E. Wollenberg. 2009. Adaptive co-management for social-ecological complexity. Frontiers in Ecology and the Environment 6:95-102.

Berkes, F. 1994. Co-management: bridging the two solitudes. Northern Perspectives 22:18-20.

Berkes, F. 2004. Rethinking community-based conservation. Conservation Biology 18(3):621630.

Berkes, F. 2007. Adaptive co-management and complexity: exploring the many faces of comanagement. Pages 19-38 in D. Armitage, F. Berkes, and N. Doubleday, editors. Adaptive comanagement: collaboration, learning and multilevel governance. University of British Columbia Press, Vancouver, British Columbia, Canada.

Berkes, F. 2009. Evolution of co-management: role of knowledge generation, bridging organizations and social learning. Journal of Environmental Management 90:1692-1702.

Berkes, F., J. Colding, and C. Folke, editors. 2003. Navigating social-ecological systems. Cambridge University Press, Cambridge, UK.

Berkes, F., and C. Folke editors. 1998. Linking social and ecological systems. Cambridge University Press, Cambridge, UK.

Berkes, F., P. J. George, and R. J. Preston. 1991. The evolution of theory and practice of the joint administration of living resources. Alternatives $\mathbf{1 8}$ (2):12-18.

Bodin, Ö., and B. Crona. 2009. The role of social networks in natural resource governance: what relational patters make a difference? Global Environmental Change, in press.

Bodin, Ö., B. Crona, and H. Ernstson. 2006. Social networks in natural resource management: what is there to learn from a structural perspective? Ecology and Society 11(2): 2. [online] URL: http:// www.ecologyandsociety.org/vol11/iss2/resp2/.

Booher, D. E., and J. E. Innes. 2002. Network power in collaborative planning. Journal of Planning Education and Research 21(3):221-236.
Carlsson, L., and F. Berkes. 2005. Comanagement: concepts and methodological implications. Journal of Environmental Management 75:65-76.

Cash, D. W., W. Adger, F. Berkes, P. Garden, L. Lebel, P. Olsson, L. Pritchard, and O. Young. 2006. Scale and cross-scale dynamics: governance and information in a multilevel world. Ecology and Society 11(2): 8. URL: http://www.ecologyandsociety. org/vol11/iss2/art8/.

Chambers, R., and G. R. Conway. 1991. Sustainable rural livelihoods: practical concepts for the 21st century. Institute of Development Studies. Discussion Paper 296. University of Sussex, Brighton, UK.

Crona, B., and Ö. Bodin. 2006. What you know is who you know? - communication patterns among resource extractors as a prerequisite for comanagement. Ecology \& Society 11(2): 7. [online] URL: http://www.ecologyandsociety.org/vol11/iss2/ $\underline{\operatorname{art} 7 /}$.

Colfer, C. J. 2005. The complex forest. Resources for the Future, Washigton, D.C., USA.

Cousins, P. D. 2002. A conceptual model for managing long-term inter-organizational relationships. European Journal of Purchasing and Supply Management 8:71-82.

Doubleday, N. 2005. From dialectic to praxis: adaptive co-management as midwife to change? In Canada's Oceans: Research, Management and the Human Dimension. Proceedings of the Ocean Management Research Network National Conference, 28 September-1 October 2005, Ottawa, Ontario, Canada. [online]

URL: http://www.omrn-rrgo.ca/?action=conferenc es 2005.sec 33.

Doubleday, N. 2007. Culturing adaptive comanagement: finding "keys" to resilience in asymmetries of power. Pages 228-248 in D. Armitage, F. Berkes, and N. Doubleday, editors. Adaptive co-management: collaboration, learning and multi-level governance. University of British Columbia Press, Vancouver, British Columbia, Canada. 
Dyball, R., S. Beavis, and S. Kaufman. 2005. Complex adaptive systems: constructing mental models. Pages 41-60 in M. Keen, V. A. Brown, and $\mathrm{R}$. Dyball, editors. Social learning in environmental management. Earthscan, London, UK.

Emery, F. E., and E. L. Trist. 1965. The casual texture of organizational environments. Human Relations 18(1):21-32.

Fabricius, C., C. Folke, G. Cundill, and L. Schultz. 2007. Powerless spectators, coping actors, and adaptive co-managers: a synthesis of the role of communities in ecosystem management. Ecology and Society 12(1): 29. [online] URL: http://www.e cologyandsociety.org/vol12/iss 1/art29/.

Farrington, J., D. Carney, C. Ashley, and C. Turton. 1999. Sustainable livelihoods in practice: early application of concepts in rural areas. ODI Natural Resources Perspectives 42(June). [online] URL: http://www.odi.org.uk/resources/specialist/naturalresource-perspectives/42-sustainable-livelihoods-inpractice-rural-areas.pdf.

Fennell, D., R. Plummer, and M. Marschke. 2008. Is adaptive co-management ethical? Journal of Environmental Management 88(1):62-75.

Folke, C. 2006. Resilience: the emergence of a perspective for social-ecological systems analyses. Global Environmental Change 16(3):253-267.

Folke, C., S. Carpenter, T. Elmqvist, L. Gunderson, C. S. Holling, B. Walker, J. Bengtsson, F. Berkes, J. Colding, K. Danell, M. Falkenmark, M. Moberg, L. Gordon, R. Kaspersson, N. Kautsky, A. Kinzig, S. A. Levin, K.-G. Mäler, L. Ohlsson, P. Olsson, E. Ostrom, W. Reid, J. Rockstöm, S. Savenije, and U. Svedin. 2002. Resilience and sustainable development: building adaptive capacity in a world of transformations. Report for the Swedish Environmental Advisory Council 2002. Ministry of the Environment, Stockholm, Sweden.

Folke, C., J. Colding, and F. Berkes. 2003. Synthesis: building resilience and adaptive capacity in social-ecological systems. Pages 252-387 in F. Berkes, J. Colding, and C. Folke, editors. Navigating social-ecological systems. Cambridge University Press, Cambridge, UK.
Folke, C., T. Hahn, P. Olsson, and J. Norberg. 2005. Adaptive governance of social-ecological systems. Annual Review of Environment and Resources 30:8.1-8.33.

Fresque, J. 2008. The evolution, experience and drivers of collaboration in two non-profit river based organizations in New Brunswick, Canada. Thesis, Brock University, St. Catharines, Canada.

Gladwell, M. 2000. The tipping point. Back Bay Books, New York, New York, USA.

Gray, B. 1989. Collaborating: finding common ground for multiparty problems. Jossey-Bass Publishers, San Francisco, California, USA.

Guillet, D. 2002. Co-management of natural resources: the long view from northwestern Spain. Environment and History 8:217-236.

Gunderson, L. H., C. S. Holling, and S. Light. 1995. Barriers and bridges to renewal of ecosystems and institutions. Columbia University Press, New York, New York, USA.

Gunderson, L. G., Peterson, and C. S. Holling. 2008. Practicing adaptive management in complex social-ecological systems. Pages 223-245 in J. Norberg and G. S. Cumming, editors. Complexity theory for a sustainable future. Columbia University Press, New York, New York, USA.

Holling, C. S., editor. 1978. Adaptive environmental assessment and management. Wiley, New York, New York, USA.

Holling, C. S. 1986. The resilience of terrestrial ecosystems: local surprise and global change. Pages 292-317 in W. C. Clark and R. E. Munn, editors. Sustainable development of the biosphere. Cambridge University Press, Cambridge, UK.

Holling, C. S. 2001. Understanding the complexity of economic, ecological, and social systems. Ecosystems 4(5):390-405.

Holling, C. S., and L. H. Gunderson. 2002. Resilience and adaptive cycles. Pages 25-62 in L. H. Gunderson and C. S. Holling, editors. Panarchy. Island Press, Washington, D.C., USA.

Holling, C. S., L. H. Gunderson, and G. D. Peterson. 2002. Sustainability and panarchies. 
Pages 63-102 in L. H. Gunderson and C. S. Holling, editors. Panarchy. Island Press, Washington, D.C., USA.

Hughes, T. P., L. H. Gunderson, C. Folke, A. H. Baird, D. Bellwood, F. Berkes, B. Crona, A. Helfgott, H. Leslie, J. Norberg, M. Nyström, P. Olsson, H. Österblom, M. Scheffer, H. Schuttenberg, R. S. Steneck, M. Tengö, M. Troell, B. Walker, J. Wilson, and B. Worm. 2007. Adaptive management of the Great Barrier Reef and the Grand Canyon world heritage areas. Ambio 36 (7):586-592.

Huitema, D., E. Mostert, W. Egas, S. Moellenkamp, C. Pahl-Wostl, and R. Yalcin. 2009. Adaptive water governance: assessing the institutional prescriptions of adaptive comanagement from a governance perspective and defining a research agenda. Ecology and Society 14 (1): 26. [online] URL: http://www.ecologyandsociety. org/vol14/iss 1/art26/.

Janssen, M. A., Ö. Bodin, J. M. Anderies, T. Elmqvist, H. Ernstson, R. R. J. McAllister, P. Olsson, and P. Ryan. 2006. A network perspective on the resilience of social-ecological systems. Ecology and Society 11(1): 15. [online] URL: http: //www.ecologyandsociety.org/vol11/iss1/art15/.

Jiggins, J., and R. Rölling. 2000. Adaptive management: potential and limitations for ecological governance. International Journal of Agricultural Resources, Governance, and Ecology 1 (1):28-42.

Johnson, B. L. 1999. Introduction to the special feature: adaptive management-scientifically sound, socially challenged? Conservation Ecology 3(1): 10. [online] URL: http://www.consecol.org/vol3/iss1/ $\underline{\operatorname{art} 10 /}$.

Kearney, J., and F. Berkes. 2007. Communities of interdependence for adaptive co-management. Pages 191-207 in D. Armitage, F. Berkes and N. Doubleday, editors. Adaptive co-management: collaboration, learning and multi-level governance. University of British Columbia Press, Vancouver, British Columbia, Canada.

Keen, M., and S. Mahanty. 2005. Collaborative learning: bridging scales and interests. Pages 104120 in M. Keen, V. A. Brown, and R. Dyball, editors.
Social learning in environmental management. Earthscan, London, UK.

Klijn, E., and J. Edelenbos. 2007. Metagovernance as network management. Pages 199_ 213 in E. Sørensen and J. Torfing, editors. Theories of democratic network governance. Palgrave Macmillan, New York, New York, USA.

Kristofferson, A. H., and F. Berkes. 2005. Adaptive co-management of Arctic char in Nunavut Territory. Pages 249-268 in F. Berkes, R. Huebert, H. Fast, M. Manseau, and A. Diduck, editors. Breaking ice. University of Calgary Press, Calgary, Alberta, Canada.

Lee, K. 1993. Compass and gyroscope: integrating science and politics for the environment. Island Press, Washington, D.C., USA.

McConney, P., R. Mahon, and R. Pomeroy. 2007. Challenges facing coastal resource co-management in the Caribbean. Pages 105-124 in D. Armitage, F. Berkes, and N. Doubleday, editors. Adaptive comanagement: collaboration, learning and multilevel governance. University of British Columbia Press, Vancouver, British Columbia, Canada.

McLain, R., and R. G. Lee. 1996. Adaptive management: promises and pitfalls. Environmental Management 20(4):437-448.

Nadasdy, P. 2003. Hunters and bureaucrats: power, knowledge, and aboriginal-state relations in the southwest Yukon. University of British Columbia Press, Vancouver, British Columbia, British Columbia, Canada.

Nadasdy, P. 2007. Adaptive co-management and the gospel of resilience. Page 208-227 in D. Armitage, F. Berkes, and N. Doubleday, editors. Adaptive co-management: collaboration, learning and multilevel governance. University of British Columbia Press, Vancouver, British Columbia, Canada.

Natcher, D. C., S. Davis, and C. G. Hickey. 2005. Co-management: managing relationships, not resources. Human Organization 64(3):240-250.

Newman, L., and A. Dale. 2005. Network structure, diversity, and proactive resilience building: a response to Tompkins and Adger. 
Ecology and Society 10(1): 2. [online] URL: http:// www.ecologyandsociety.org/vol10/iss1/resp2/.

Nkhata, A. B., C. M. Breen, and W. A. Freimund. 2008. Resilient social relationships and collaboration in the management of social-ecological systems. Ecology and Society 13(1): 2. [online] URL:http:// www.ecologyandsociety.org/vol13/iss1/art2/.

Noble, B. F. 2004. Applying adaptive environmental management. Pages 442-466 in B. Mitchell, editor. Resource and environmental management in Canada. Oxford University Press, Don Mills, Ontario, Canada.

Olsson, P. 2007. The role of vision in framing adaptive co-management processes: lessons form Kristianstads Vattenrike, Southern Sweden. Pages 268-285 in D. Armitage, F. Berkes, and N. Doubleday, editors. Adaptive co-management: collaboration, learning and multi-level governance. University of British Columbia Press, Vancouver, British Columbia, Canada.

Olsson, P., C. Folke, and F. Berkes. 2004a. Adaptive co-management for building resilience in social-ecological systems. Environmental

Management 34:75-90.

Olsson, P., C. Folke, V. Galaz, T. Hahn, and L. Schultz. 2007. Enhancing the fit through adaptive co-management: creating and maintaining bridging functions for matching scales in the Kristianstads Vattenrike Biosphere Reserve Sweden. Ecology and Society 12(1): 28. [online] URL: http://www.e cologyandsociety.org/vol12/iss1/art28/.

Olsson, P., C. Folke, and T. Hahn. 2004b. Socialecological transformation for ecosystem management: the development of adaptive co-management of a wetland landscape in southern Sweden. Ecology and Society 9(4): 2. [online] URL: http://www.ecol ogyandsociety.org/vol9/iss4/art2.

Olsson, P., L. H. Gunderson, S. R. Carpenter, P. Ryan, L. Lebel, C. Folke, and C. S. Holling. 2006. Shooting the rapids: navigating transitions to adaptive governance of social-ecological systems. Ecology and Society 11(1): 18. [online] URL: http: //www.ecologyandsociety.org/vol11/iss1/art18/.

Ostrom, E. 2007. A diagnostic approach for going beyond panaceas. Proceedings of the National Academy of Sciences 104(39):15181-15187.
Pinkerton, E. 1989. Attaining better fisheries management through co-management prospects, problems and propositions. Pages 3-33 in E. Pinkerton, editor. Co-operative management of local fisheries: new direction in improved management and community development. University of British Columbia Press, Vancouver, British Columbia, Canada.

Plummer, R. 2006. Sharing the management of a river corridor: a case study of the co-management process. Society and Natural Resources 19:1-13.

Plummer, R., and D. Armitage. 2007a. A resilience-based framework for evaluating adaptive co-management: linking ecology, economy and society in a complex world. Ecological Economics 61:62-74.

Plummer, R., and D. R. Armitage. 2007b. Charting the new territory of adaptive comanagement: a Delphi study. Ecology and Society 12(2): 10. [online] URL: http://www.ecologyandso ciety.org/vol12/iss2/art10/.

Plummer, R., and D. Armitage. 2007c. Crossing boundaries, crossing scales: the evolution of environment and resource co-management. Geography Compass 1(4):834-849.

Plummer, R., and D. Fennell. 2007. Exploring comanagement theory: prospects for sociobiology and reciprocal altruism. Journal of Environmental Management 85:944-955.

Plummer, R., and J. FitzGibbon. 2004a. Comanagement of natural resources: a proposed framework. Environmental Management 33 (6):876-885.

Plummer, R., and J. E. FitzGibbon. 2004b. Some observations on the terminology in co-operative environmental management. Journal of Environmental Management 70:63-72.

Plummer, R., and J. E. FitzGibbon. 2007. Connecting adaptive co-management, social learning and social capital through theory and practice. Pages 38-61 in D. Armitage, F. Berkes, and N. Doubleday, editors. Adaptive comanagement: collaboration, learning and multilevel governance. University of British Columbia Press, Vancouver, British Columbia, Canada. 
Pomeroy, R. S., and F. Berkes. 1997. Two to tango: the role of government in fisheries co-management. Marine Policy 21(5):465-480.

Ruitenbeek, J., and C. Cartier. 2001. The invisible wand: adaptive co-management as an emergent strategy in complex bio-economic systems. Center for International Forestry Research (CIFOR) Occasional Paper 34, CIFOR, Bogor, Indonesia. [online] URL: http://www.cifor.cgiar.org/publications/ pdf files/OccPapers/OP-034.pdf.

Scheffer, M., F. Westley, W. A. Brock, and M. Holmgren. 2002, Dynamic interactions of societies and ecosystems-linking theories from ecology, economy and sociology. Pages 195-240 in L. H. Gunderson and C. S. Holling, editors. Panarchy. Island Press, Washington, D.C., USA.

Schultz, L. 2009. Nurturing resilience in socialecological systems. Dissertation. Stockholm University, Stockholm, Sweden.

Scoones, I. 1998. Sustainable rural livelihoods: a framework for analysis. Working Paper, vol. 72. Institute of Development Studies (IDS), Brighton, UK. [online] URL: http://www.ids.ac.uk/download. $\underline{\text { cfm?file }=\text { wp72.pdf. }}$.

Seixas, C. S., and F. Berkes. 2003. Dynamics of social-ecological changes in a lagoon fishery in southern Brazil. Pages 271-298 in F. Berkes, J. Colding, and C. Folke, editors Navigating socialecological systems. Cambridge University Press, Cambridge, UK.

Selin, S., and D. Chavez. 1995. Developing an evolutionary tourism partnership model. Annals of Tourism Research 22(4):844-856.

Singleton, S. 2002. Collaborative environmental planning in the American West: the good, the bad and the ugly. Environmental Politics 11(3):54-75.

Sørensen, E., and J. Torfing, editors. 2007. Theories of democratic network governance. Palgrave Macmillan, New York, New York, USA.

Tompkins, E. L., and W. N. Adger. 2004. Does adaptive management of natural resources enhance resilience to climatic change? Ecology and Society 9 (2): 10. [online] URL: http://www.ecologyandsociety. org/vol9/iss2/art10/.
Trist, E. 1983. Referent organizations and the development of inter-organizational domains. Human Relations 36(3):269-284.

Turner, J. H. 1994. The structure of sociological theory. Fifth edition. Wadsworth Publishing Company, Belmont, California, USA.

Walters, C. J. 1986. Adaptive management of renewable resources. MacMillan Publishing Company, New York, New York, USA.

Walters, C. J. 2007. Is adaptive management helping to solve fisheries problems? Ambio 36 (4):304-307.

Walters, C. J., and C. S. Holling. 1990. Largescale management experiments and learning by doing. Ecology 71(6):2060-2068

Walker, B. H., L. H. Gunderson, A. P. Kinzig, C. Folke, S. R. Carpenter, and L. Schultz. 2006. A handful of heuristics and some propositions for understanding resilience in social-ecological systems. Ecology andSociety 11(1): 13. [online] URL: http://www.ecologyandsociety.org/vol11/iss1/ $\underline{\operatorname{art13}}$.

Westley, F. 2002. The devil in the dynamics: adaptive management on the front lines. Pages 333 360 in L. H. Gunderson and C. S. Holling, editors. Panarchy. Island Press, Washington, D.C., USA.

Westley, F., S. R. Carpenter, W. A. Brock, C. S. Holling, and L. H. Gudnerson. 2002. Why systems of people and nature are not just social and ecological systems. Pages 103-120 in L. H. Gunderson and C. S. Holling, editors. Panarchy. Island Press, Washington, D.C., USA. 